\title{
EMOTIONAL FACTORS IN SENIOR L2 ACQUISITION: A CASE STUDY OF JAPANESE SPEAKERS LEARNING SPANISH
}

\author{
EMI SHIBUYA \\ Graduate School of Foreign Language Studies, \\ Kobe City University of Foreign Studies \\ 9 Chome-1 Gakuen Higashimachi, \\ Nishi-ku Kobe-shi, Hyogo-ken 651-2187, Japan \\ Email address: emishibuya@hotmail.com \\ ORCID: https://orcid.org/0000-0003-1980-9320
}

\begin{abstract}
Aim. This research explores whether a training course on tour guiding in a foreign language designed for senior learners could make the most of their life experience, knowledge, and motivation (Shibuya, 2018, 2019). The article argues that language learning for older adults is to be considered not only from cognitive aspects, but also from emotional and social aspects, since these are malleable and susceptible of being changed by the teaching method and the teacher's skills.

Method. We discuss the case of senior Japanese learners of Spanish based on their answers to the questionnaires, class observations and introspective materials. Literature regarding emotional factors such as tolerance to ambiguity is reviewed. Also, we further focus on the social factors including gender divide, a major issue in Japanese society that affects the older generation in particular.

Results. We used the Multidimensional Mood State Questionnaire (MDMQ questionnaire, English version of Der Mehrdimensionale Befindlichkeitsfragebogen MDBF; Steyer, Schwenkmezger, Notz, and Eid, 1997) to determine their mood before and after the class 5 times in total. For the purpose of this paper, we introduce 4 learners' cases ( 2 female and 2 male learners).

Conclusion. A content-based course linked to practical occasions to be a volunteer tour guide seems not simple for the learners and some of them felt ambiguous with regards to the contents; however, independently of their Spanish level, they tried to find simple and alternative ways to manage the conversations or explanations. Some typical cultural and social factors in Japan, learners' language level, experience, knowledge, and emotional factors seem more important elements for the creation of class atmosphere in this content-based L2 learning.
\end{abstract}

Key words: Emotional factors, Senior L2 learning, Japanese L2 learners, Introspective diaries on language learning, Qualitative research on L2 acquisition 


\section{BACKGROUND OF STUDY}

In 2019, a new era called Reiwa started in Japan. In this new era, it is said that we are facing a "100-year life society". In our aging society, it is crucial to consider the role of lifelong learning.

Kobe City University of Foreign Studies launched a senior Spanish course as L2 aimed at 60-year-olds or over in 2013. When it comes to senior language learning, low expectations for students' progress are common on the part of teachers (Ramírez Gómez, 2016; see also Shibuya, 2018). Following the guidelines of Danya Ramírez Gómez (2016) regarding the necessity of using senior students' life experience as part of the content for language lessons, and faithful to our pedagogical conviction about achieving results and not exercising patronising teaching, we decided to add to the programme a content-based language course in 2018 with the aim of turning senior learners into volunteer tour guides. At this time, we experienced increasing numbers of visitors due to some inbound business opportunities scheduled for the Olympic and Paralympic Games in Tokyo in 2020 and for World EXPO 2025, Osaka, Kansai, Japan. Given the life experience of older adults, it seemed to us that tour guiding as professionals or volunteers would enable them to undertake and continue learning foreign languages and it would provide them with communication opportunities. Dealing with foreigners requires not only language skills, but also an understanding of the visitors' countries and interpersonal skills. These types of activities give learners lifelong learning opportunities and motivation to use their accumulated knowledge in international settings (see also Shibuya, 2018, 2019).

\section{THE PILOT SPANISH COURSE ON VOLUNTEER TOUR GUIDING}

Although the overview and introduction of this pilot Spanish course on volunteer tour guiding were discussed in Emi Shibuya (2018, 2019), below we introduce the pilot Spanish course conducted from the spring of 2018, a course which was co-taught by four native speakers and which lasted 15 weeks, from April to July of 2018, in weekly 90-minute sessions. The data was from spring 2018 and spring 2019. Teachers use tour guiding content, and learners study the target language with specific purposes through topics that interest them. This course sought to create group synergies and a motivating atmosphere for senior learners.

In the spring of 2018, ten female and six male learners ranging from 57 to 75 years of age took the volunteer tour guide course. We originally had more registrations on this course, however, some of them could not continue due to their personal reasons. In senior classes, we have to consider this aspect because of the learners' family or health issues, etc. Most of them were regular attendees of the language courses divided into four levels that had been held continuously from five years before and therefore, they attended the volunteer tour guide 
course after taking a regular language course. The learners of the volunteer tour guide course had taken a level assessment that focused mainly on grammar, vocabulary, and expressions. For assigning their levels, we referred to the guidelines of the Common European Framework (Council of Europe, 2001, Table 1. Common Reference Levels: global scale). The first level assessment test results for this course (that 12 learners took) ranged from B2 (three males and two females), B1 (two males and one female), and A2 (four females). Thus, there was an ample range of levels in the 2018 volunteer tour guide course.

In the spring of 2019, we continued this volunteer tour guide course with the same concept of content and class setting. Fifteen learners regularly took part in the class (ten females and five males). Their level ranged from B2 (six females and three males) and B1 (four females and two males). Eleven learners from this second course had also taken the course in the previous year. Six learners were B2 (two females were B2 and the other two females did not take level tests the previous spring; and one male was B2 and the other male was B1 the previous spring), and five learners were B1 level (two females were A2 level and the other female did not take a level test the previous spring; and one male was B1 and the other male was B2 the previous spring). Thus, most of the learners' level had improved compared to the previous year, except one of the learners whose level was lowered from B2 to B1. This learner, however, seemed to start learning another language and focus more on learning hobbies using a foreign language.

Both spring 2018 and 2019 courses applied the communicative approach and role-playing activities around issues related to religion, tradition, lifestyle and culture in Japan. We collected the following data though we do not have the data for all participants.:

- Preliminary questionnaire about learners' backgrounds (their experience in studying foreign languages, volunteering, working, and social activities) and about their motivation and expectations for this course;

- A level test at the beginning of the spring course in 2018 and 2019;

- Video recording while they are role-playing in the class;

- Diaries about their language learning experience;

- Some comments from the learners and discussion of the general course organisation with the class and the teachers in 2018;

- Interviews after the spring 2019 course;

- Multidimensional Mood State Questionnaire (MDMQ questionnaire, English version of MDBF; Steyer, Schwenkmezger, Notz, \& Eid, 1997) by our translation into Japanese before and after the class three times (in May, June, and July) in 2018 and twice (in June and July) in 2019

Through their comments or activities in class, we got the impression that some social factors affecting that generation in Japan are at play. We tried to identify the tendencies based on cultural issues and policies in Japan, and on psychological aspects of the third age learners. This is the focus of this paper. In this study, we will be analysing only some of the collected data, in particular diaries, interviews, and mood questionnaires. 


\section{SOCIAL AND CULTURAL FACTORS IN JAPAN}

In this section, we firstly focus on social factors in Japan. Especially, when talking about older adults, it is important to describe how these people received their education and what influences they show from their society and their culture. Geert Hofstede, Gert Jan Hofstede, and Michael Minkov (2010) compare different cultures according to some parameters. According to them, Japan ranks 35-37"t for "TABLE 4.1 Individualism Index (IDV) Values for 76 Countries and Regions Based on Factor Scores from 14 Items in the IBM Database Plus Extensions" (Hofstede, Hofstede, \& Minkov, 2010, pp. 95-97). The benefit of the group is relatively respected over the benefit of the individual. This might mean that students are likely to listen to opinions of others in class first and keep or hold their individual ideas to themselves. In terms of masculinity versus femininity, Japan holds the second position in their ranking for "TABLE 5.1 Masculinity Index (MAS) Values for 76 Countries and Regions Based on Factor Scores from 14 Items in the IBM Database Plus Extensions" (Hofstede, Hofstede, \& Minkov, 2010, pp. 141-143). This is transferred to the class, in which men have traditionally been given priority and women are expected to behave in a female manner. They also show that Japan ranks high in uncertainty avoidance and masculinity measures according to "FIGURE 6.1 Masculinity Versus Uncertainty Avoidance" (Hofstede, Hofstede, \& Minkov, 2010, p. 214).

As Khrystyna Kachmaryk, Sophia Grabovska, Kateryna Ostrovska, and Viktor Syniev (2014) point out through the experimental research, the majority of the learners of the University of the Third Age show less tolerance to ambiguity or uncertainty situations, while the elderly who do not study develop the skill of social interaction. In our experience, in the Spanish courses, some senior learners have raised issues or concerns to teachers directly often outside of the class to try to make it clear and share their ideas or sympathies regarding their communication difficulties.

In class, we usually see senior learners' openness and no stress from exam pressures. However, and even though G. Hofstede, G. J. Hofstede, and M. Minkov (2010, p. 149) claim that "When people grow older, they tend to become more social and less ego oriented (lower MAS)", when it comes to group work, we observed some stubborn attitudes or ideas that they cannot give up as some of them also noted in their diaries.

G. Hofstede, G. J. Hofstede, and M. Minkov (2010) also include Confucian ideas of obligations for some Asian countries including Japan and they state that "These relationships contain mutual and complementary obligations: for example, the junior partner owes the senior respect and obedience, while the senior partner owes the junior protection and consideration" (p. 80). In the senior language class, teachers are often younger than senior learners. Some senior learners try to impose their expectations onto the class and want their ideas about how to proceed or even about changing the lesson contents to be listened to. On the other hand, some of them are quite flexible and try to collaborate in all possible ways.

Secondly, we focus on older adults' social factors in Japan as affected by public policies. According to the policy in the Annual Report on the Aging Society: 2018 
Summary (Cabinet Office, Government of Japan, 2018, Chapter 2, Situation Regarding Implementation of Measures for the Ageing Society), the government encourages older adults to find jobs, continue education, and be involved in social contributions. The following are some of the ways in which this happens:

- Silver Human Resources Center as an institution to give older adults employment chances as well as procure older adults involvement in society;

- Some educational institutions including universities offer re-learning opportunities for working generations as well as older adults to continue the process of lifelong learning;

- More and more promoted ICT usage for older adults;

- Older adults' social participation as a consequence of generating their objective for the purpose of life which are termed "Community Cooperation Activities for Learning and Education" (Cabinet Office, Government of Japan, 2018, p. 82) and "Project to Promote Activities to Allow the Older People to Find Reasons for Living" (Cabinet Office, Government of Japan, 2018, p. 82); and

- Encouragement toward all generations to think of our aging society through “The Japan's Plan for Dynamic Engagement of All Citizens" (Cabinet Office, Government of Japan, 2018, p. 86).

Thirdly, when we focus on older adults' social factors in Japan through sexism in education, job, and career opportunities, it is said that there seems to be a hidden agenda: we receive education to be manly or womanly, and such roles are created from childhood (Muramatsu, 2003; Mori, 2009). School textbooks used a lot of male models, and some subjects such as homemaking were for women students at school some decades ago in Japan (Muramatsu, 2003; Amano, 2009, p. 60). School subjects like Science tend to be believed to be for men in Japan, and there seems to be a gender bias there (Muramatsu, 2009). According to Akira Kawaguchi (2013), universities were originally for men, and junior colleges for women, and women started to pursue higher education, shifting to university from junior college only in the 1990s in Japan. There are still women's universities in Japan. In terms of job recruiting, career patterns for women are closely related to gender issues (Yoshihara, 1995). We hypothesize that the above patterns of placing men first and expecting women to behave in more womanly ways should be found in older adults' classes in Japan. We will discuss this later in relation to our findings.

\section{TOLERANCE TO AMBIGUITY}

As we said above, both cognitive and emotional/social factors have been discussed in the literature on L2 acquisition. Regarding emotional factors such as tolerance of ambiguity, rigidity and intolerance of ambiguity have close relationship (Budner, 1962; Norton 1975). Students holding a high intolerance of ambiguity might have difficulty in dealing with the L2 classroom (Naiman, Fröhlich, Stern, \& Todesco, 1996). Amin Marzban, Hossein Barati, and Ahmad 
Moinzadeh (2012) discuss gender differences in relation to ambiguity tolerance, showing that women are relatively less tolerant towards ambiguity in the language learning context than men in their study on EFL undergraduate students, however their statistical analysis shows that it was not a significant difference. Mohamad Syafiq Bin Ya Shak's (2015) study between students' tolerance of ambiguity and language learning strategy usage does not show significance in relationship but positive outcome, and recommending the importance of using communicative ways, e.g. role-plays, simulations, and group discussions, etc. as the possibility of different language learning strategies.

Our senior volunteer tour guide course is a content-based learning course. By its own nature and objectives, many issues about Japan that are discussed in the materials have no unique definition or correct answer. A few learners who have a higher proficiency level of language commented in their diaries that they feel that the contents are not clear and therefore they decided not to continue the course after the first semester as it seemed ambiguous to them. However, most of our participants not only remained until the end, but also decided to take the course again a second time.

\section{THE LEARNERS' PSYCHOLOGICAL DIMENSION}

This research tries to determine whether this training course on tour guiding in Spanish designed for senior learners as L2 contributes to making the maximum use of their life experience, knowledge, and motivation (Shibuya, 2018, 2019). In regular language courses, in general, learners quit in the middle of the course if they feel that the class level is too high for them to follow. However, in this pilot course, even though it is not easy, almost none of the regular learners quit until the end of the semester. It became obvious to us that this course elicited different feelings than a regular language class.

To measure these psychological aspects, we prepared a Japanese version of the Multidimensional Mood State Questionnaire (translating from English version). The English version of MDMQ questionnaire consists of 24 items with six answer categories, intended to measure three dimensions: the actual state of wellbeing, being awake and alert, and calmness (Department of Methodology and Evaluation Research, University of Jena, n.d.). GB means Good and Bad. AT means Awake and Tired. CN means Calm and Nervous. Each of these three dimensions of the actual mood state is measured by eight items negatively or positively formulated. Higher scores indicate that their mood is good and lower scores signal that their mood is bad in the three dimensions. Before and after the class, we collected data three times in May, June and at the last class of the spring course in July in 2018 as well as in June and July of the spring course in 2019. We show individual tendencies concerning their mood throughout the course. The scarce number of participants does not allow for a detailed cross-subjects statistical analysis. Table 1 shows the data for four of the learners. We include their introspective materials results to explore their 
Journal of Education Culture and Society No. 1_2020

emotional aspects in the next section. Their summaries here were checked and agreed individually with clarification of the purpose of the research, their data's confidentiality, and preserving participants privacy.

Table 1.

Distribution of four learners

\begin{tabular}{ccccc}
\hline Learners & Age & Gender & $\begin{array}{c}\text { Spanish Level in } \\
2018\end{array}$ & $\begin{array}{c}\text { Spanish Level } \\
\text { in 2019 }\end{array}$ \\
\hline S13 & Early 70s & Female & A2 & B1 \\
S1 & Early 70s & Male & B1 & B2 \\
S7 & Mid 60s & Female & B2 & B2 \\
S9 & Late 60s & Male & B2 & B2 \\
\hline
\end{tabular}

Source: author's research

\section{MDMQAND INTROSPECTIVE RESULTS}

Figure 1 illustrates the case of S13. Her mood for all the categories improved a lot for every time after the class, except GB and no change of AT in June 2019, right after she had come back from a trip to a Spanish-speaking country that kept her away for six months from the course participation.
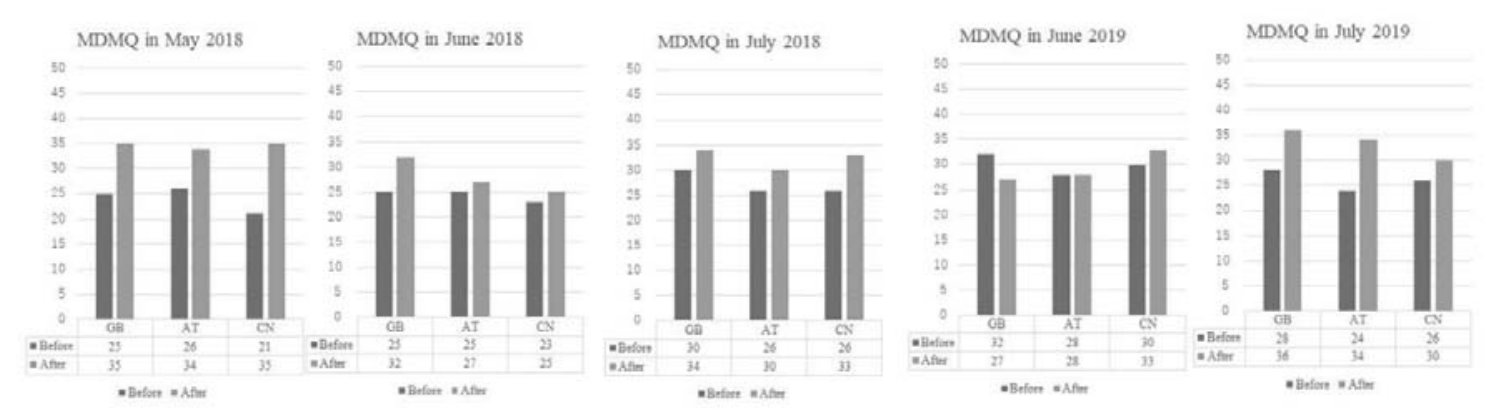

Figure 1. Results of the Multidimensional Mood State Questionnaire (MDMQ) of $\mathrm{S} 13$

Source: Author's research upon questionnaire

She took the volunteer tour guide course in the spring of 2018 but did not follow the course in the autumn of 2018. She restarted this course in the spring of 2019. Her level was considered to be A2 in 2018 and it became B1 level in 2019. She had studied Spanish for five years previously and had travelled several times to Spanish speaking countries. She also has six months experience as an expatriate's spouse in a Spanish speaking country and also joined a short-term study trip in Spain after starting our senior Spanish course in the past. Her motivation to follow this volunteer tour guide course was that her Spanish level had not improved as expected and she wanted to try learning in a different way. She thought the volunteer tour guide course would provide more 
opportunities to communicate with others. Concerning the main question of this paper (whether this type of content-based instruction maximizes their life experience and leads to more motivation), let us observe her comments.

Table 2.

Highlights of the diary from S13.

\begin{tabular}{|c|c|}
\hline Spring, 2018 & Spring, 2019 \\
\hline $\begin{array}{l}\text { "I noticed that I did not know many things about } \\
\text { Japan and did not have much interest in them" (April } \\
18,2018 \text { ). }\end{array}$ & $\begin{array}{l}\text { "It is difficult to explain the } \\
\text { differences between Buddhism } \\
\text { and Shintoism as I rarely think } \\
\text { about them in my daily life" } \\
\text { (May 29, 2019). }\end{array}$ \\
\hline $\begin{array}{l}\text { "I am questioning the contents of the course. All we } \\
\text { need to explain to tourists are actually the daily things } \\
\text { about Japan that we, Japanese already know" (April } \\
18,2018 \text { ). }\end{array}$ & \multirow{2}{*}{$\begin{array}{l}\text { "In class, we had students' } \\
\text { presentations about differences } \\
\text { between Buddhism and Shintoism } \\
\text { but I am wondering if there is } \\
\text { any need to explain differences } \\
\text { in detail and in a complicated } \\
\text { manner" (June 19, 2019). }\end{array}$} \\
\hline $\begin{array}{l}\text { "I researched the internet about volunteer guide } \\
\text { activities at home and started to understand how guides } \\
\text { are studying and preparing well in advance of their } \\
\text { activities. By knowing that fact, I felt like moving ahead } \\
\text { though I still feel down somehow" (April 18, 2018). }\end{array}$ & \\
\hline $\begin{array}{l}\text { "I felt very nervous in class. I am uncomfortable with } \\
\text { my level of Spanish and wondered what I had been } \\
\text { doing these five years" (April 25, 2018). }\end{array}$ & \multirow{2}{*}{$\begin{array}{l}\text { "We need to know the contents } \\
\text { well and should have interest in } \\
\text { the topics so that we can explain } \\
\text { them concisely and briefly to the } \\
\text { guests who do not know much } \\
\text { about Japan" (June 26, 2019). }\end{array}$} \\
\hline $\begin{array}{l}\text { "I should keep learning and at the same time, make } \\
\text { use of what I know and try to explain with the words } \\
\text { I can manage in Spanish" (May 9, 2018). }\end{array}$ & \\
\hline $\begin{array}{l}\text { "Some of the speech from the class was difficult to } \\
\text { understand. I wish they would speak briefly and in a } \\
\text { way that is easy to understand" (May 9, 2018). }\end{array}$ & \multirow{2}{*}{$\begin{array}{l}\text { "We have different types of } \\
\text { guests and their interests vary } \\
\text { a lot. As a guide, it is important } \\
\text { to have interest in topics and we } \\
\text { need to study topics as well as } \\
\text { learning Spanish" (July 3, 2019). }\end{array}$} \\
\hline $\begin{array}{l}\text { "I am feeling that it is harder to continue the course } \\
\text { and cannot enjoy the course at all as I feel I have not a } \\
\text { good level of Spanish" (June 26, 2018). }\end{array}$ & \\
\hline $\begin{array}{l}\text { "The course contents are not clear without a specific } \\
\text { program and explanation at the beginning of the } \\
\text { course, though it changed somehow after the } \\
\text { discussion we had in class previously" (June 26, 2018). }\end{array}$ & \multirow[t]{2}{*}{$\begin{array}{l}\text { "When speeches are too long, } \\
\text { people feel bored of listening. } \\
\text { I should contrive to make it } \\
\text { interesting" (July 10, 2019). }\end{array}$} \\
\hline $\begin{array}{l}\text { "I wonder if there are any co } \\
\text { tests we had before" (June } 26\end{array}$ & \\
\hline $\begin{array}{l}\text { "Teachers and classmates' speaking speeds are too } \\
\text { fast to follow and I am overwhelmed“ (June 26, 2018). }\end{array}$ & \multirow{2}{*}{$\begin{array}{l}\text { "The role-playing practice for } \\
\text { guiding in the class is a very } \\
\text { interesting opportunity for } \\
\text { learning and practicing Spanish' } \\
\text { (July 10, 2019). }\end{array}$} \\
\hline $\begin{array}{l}\text { "I have been too negative all throughout the course } \\
\text { and realised finally that the important thing was } \\
\text { to manage as much as I could with my current } \\
\text { knowledge" (July 18, 2018). }\end{array}$ & \\
\hline
\end{tabular}

Note: translation by authors

Source: author's research 
As will be discussed later in the Discussion section, a shift from her shortcomings to a concern for the needs of visitors is observed in the diary of this learner. She focuses less and less on her own level and seeks to understand what the tourists need. She realises that all she needs is her knowledge of Japanese way of life and general culture. Through the interview, we observed that despite her difficulties to keep working on these topics, she always tried to find the solutions by herself or the best way to continue learning. She mentioned using internet or new technologies (devices or applications software) or taking some breaks and travelling abroad and coming back to this course after refreshment. This encouraged her to keep working in a new phase of the language learning.

The following is the result of S1. Due to some missing data, June 2019 was not included in Figure 2. His mood becomes slightly better or shows no significant changes for each category after the class, except decrease of GB in May 2018 and AT in July 2018.

2018

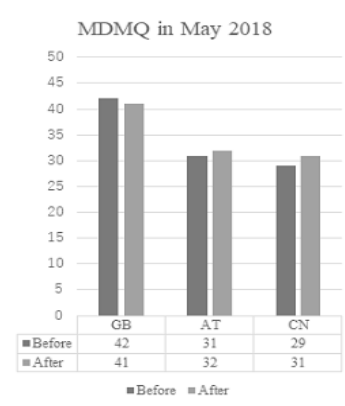

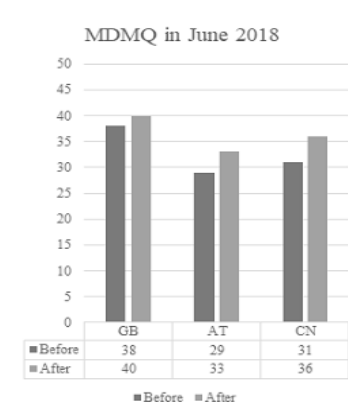
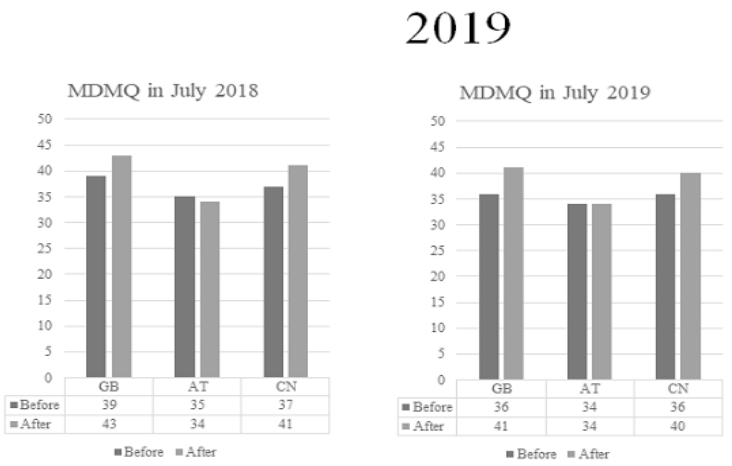

Figure 2.

Results of the Multidimensional Mood State Questionnaire (MDMQ) of S1 Source: Author's research upon questionnaire

He had studied Spanish for five years previously and had travelled several times to Spanish speaking countries. Besides, he keeps learning Western European history at the university. He followed the volunteer tour guide course from the spring of 2018 and continued in the spring of 2019. His level was considered B1 in 2018 and after a year, it was ranked B2. His motivation to follow this volunteer tour guide course was to try to understand what are the interests of Spanish speaking people visiting Japan and how to respond to them as a host. Table 3 shows some highlights from his comments.

His diary shows that this learner is very aware of the visitors' needs and he is focusing his learning process into finding the best ways to express things in Spanish, in a way that is most useful for the tourists. At the interview, he mentioned that he received the first prize for the speech contest among senior learners after the third year trial in the end of the 2018 semester. The comparison of Japanese and Western culture issues were the topics in his presentation. He seems to be proud of this experience. His awareness of choosing the best topics and speaking out by imagining the audiences' expectation seems to bring this result. 
Table 3.

Highlights of the diary from S1.

\begin{tabular}{|c|c|}
\hline Spring, 2018 & Spring, 2019 \\
\hline $\begin{array}{l}\text { "On the first day, I felt nervous at the beginning" } \\
\text { (April 18, 2018). }\end{array}$ & \multirow{2}{*}{$\begin{array}{l}\text { "Some classmates explained the } \\
\text { details but were not interacting } \\
\text { much“ (June 5, 2019). }\end{array}$} \\
\hline $\begin{array}{l}\text { "It is important to be brief and to be understood } \\
\text { easily by the guests as a tour guide" (April 18, } \\
\text { 2018). }\end{array}$ & \\
\hline $\begin{array}{l}\text { "It is better to grab the other party's interests } \\
\text { by asking questions first. It means that the first } \\
\text { explanation from a guide is actually to give a } \\
\text { chance of raising questions of visitors since each of } \\
\text { them from Spain has different interests“ (April 25, } \\
\text { 2018). }\end{array}$ & \multirow{2}{*}{$\begin{array}{l}\text { "Some explanations on some } \\
\text { concepts from the class presentation } \\
\text { lack consideration of any visual or } \\
\text { deep insight of things. If we tried to } \\
\text { speak in such manner, we would } \\
\text { require high skills for speaking } \\
\text { and it is doubtful if messages could } \\
\text { be properly transferred to others. } \\
\text { Therefore, it is important to use } \\
\text { short phrases, then make it deeper } \\
\text { by talking step by step" (June 12, } \\
\text { 2019). }\end{array}$} \\
\hline $\begin{array}{l}\text { „We had an exchange event with visitors from } \\
\text { a senior volunteer guide group from Spain. My } \\
\text { group made a presentation on 'how to behave at } \\
\text { the shrines and temples'. It was not a very deep } \\
\text { talk, but it was concrete, and I believe we could } \\
\text { convey the meanings" (May 23, 2018). }\end{array}$ & \\
\hline $\begin{array}{l}\text { "In order to explain well to the foreign visitors, } \\
\text { I believe it is important to have 'historical and } \\
\text { cultural knowledge', 'real experience or visit', and } \\
\text { 'specialised fields'“ (June 6, 2018). }\end{array}$ & \multirow{6}{*}{$\begin{array}{l}\text { "We had a role-playing activity as } \\
\text { a guide and a visitor in class. While } \\
\text { demonstrations were done by each } \\
\text { group, we tended to speak more } \\
\text { as a role of guide. It looked like a } \\
\text { one-way communication between } \\
\text { a guide and a guest. I wondered } \\
\text { whether guests could understand } \\
\text { the conversation as well as whether } \\
\text { we could have real conversations in } \\
\text { this way" (July 11,2019). }\end{array}$} \\
\hline $\begin{array}{l}\text { „I thought we had prepared the scenario; however, } \\
\text { it was not enough to explain. Probably, we could } \\
\text { not imagine well enough the partner's stereotypes } \\
\text { or interests“ (June 13, 2018). }\end{array}$ & \\
\hline $\begin{array}{l}\text { "Idiomatic phrases can be used in our } \\
\text { conversations in a reflective way" (June 20,2018). }\end{array}$ & \\
\hline $\begin{array}{l}\text { "We should keep the conversation simple and } \\
\text { reflective. It is sometimes necessary to react } \\
\text { without delving deeply into the other person's } \\
\text { story" (June 27, 2018). }\end{array}$ & \\
\hline $\begin{array}{l}\text { "It is better to use more gestures and also keep the } \\
\text { conversation as it is" (July 4, 2018). }\end{array}$ & \\
\hline $\begin{array}{l}\text { "We should try 'difficult things to be easy, } \\
\text { easy things to be deeper, and deep things to be } \\
\text { interesting' (citing from Inoue, 1989)“ (July 18, } \\
\text { 2018). }\end{array}$ & \\
\hline
\end{tabular}

Note: translation by authors

Source: author's research

The following figure shows the case of S7. Her mood generally increased or showed no significant changes after the class, except decrease of AT and CN after the class in May 2018. 

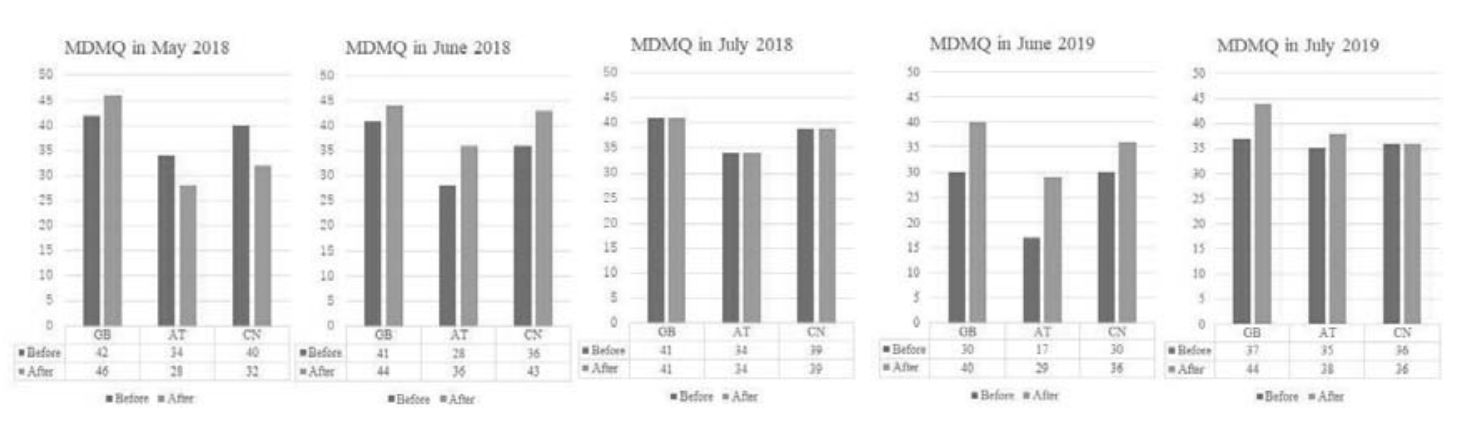

Figure 3.

Results of the Multidimensional Mood State Questionnaire (MDMQ) of S7

Source: Author's research upon questionnaire

She studied Spanish for 28 years previously and worked for a foreign diplomatic organisation. Her major was English at her higher education. She followed the volunteer tour guide course from the spring of 2018 and continued in the spring of 2019. Her level was considered B2 both in 2018 and 2019. Her motivation to follow this volunteer tour guide course was that she wanted to make use of her language learning experiences toward others and for herself. Some highlights from her diary are as Table 4.

\section{Table 4.}

Highlights of the diary from S7.

\begin{tabular}{|c|c|}
\hline Spring, 2018 & Spring, 2019 \\
\hline $\begin{array}{l}\text { "I looked forward to learning new knowledge and } \\
\text { expressions in Spanish" (April 18, 2018). }\end{array}$ & \multirow{2}{*}{$\begin{array}{l}\text { "Each group explained the } \\
\text { Shintoism and Buddhism, and } \\
\text { every explanation is correct. } \\
\text { I wanted to know the most } \\
\text { important fact to convey to the } \\
\text { guests" (June } 12,2019 \text { ). }\end{array}$} \\
\hline $\begin{array}{l}\text { "Others researched topics in detail and I was } \\
\text { surprised at their work but on the other hand I felt it is } \\
\text { not necessary to explain so much in detail" (April 25, } \\
\text { 2018). }\end{array}$ & \\
\hline $\begin{array}{l}\text { "Something I was interested in the class is that we } \\
\text { discussed similar points and different aspects in } \\
\text { Buddhism and Shintoism" (May 9, 2018). }\end{array}$ & \multirow{2}{*}{$\begin{array}{l}\text { "It is difficult to explain to the } \\
\text { [foreign] visitors in an easy } \\
\text { manner about the festivals or } \\
\text { annual events typical in Japan" } \\
\text { (June 26, 2019). }\end{array}$} \\
\hline $\begin{array}{l}\text { "It is not necessary to explain in detail but better to } \\
\text { use 5W1H (Who, When, Where, What, Why, How) } \\
\text { techniques" (June 6, 2018). }\end{array}$ & \\
\hline $\begin{array}{l}\text { "In class, we learned stereotypes about other cultures } \\
\text { and their concepts. I learned a lot of expressions, but I } \\
\text { felt that it was difficult to use them. I wish I could use } \\
\text { them naturally“ (June 20, 2018). }\end{array}$ & \multirow{2}{*}{$\begin{array}{l}\text { "Our pair chose a festival, } \\
\text { Nagasaki Kunchi as a role- } \\
\text { playing practice. Other groups } \\
\text { prepared Awa dance for class } \\
\text { speech and presentation and it } \\
\text { seemed popular in class" (July } \\
\text { 10, 2019). }\end{array}$} \\
\hline $\begin{array}{l}\text { "It is difficult to master all the expressions, but I would } \\
\text { try little by little“, "Some groups during the role-play } \\
\text { are using dialogues with guests well, but our group } \\
\text { is just explaining the itinerary. We should have used } \\
\text { more dialogues" (July } 25,2018 \text { ). }\end{array}$ & \\
\hline
\end{tabular}

Note: translation by authors

Source: author's research 
According to the interview, in the first year, the learners of the class seemed to have a higher Spanish level and the class offered more chances to talk and discuss more deeply. She does not follow any of the other level Spanish courses. Key phrases and the typical answers based on experiences are to be selected as she put it, "upon the necessity of the guests, we need to adjust". She feels that content-based practical opportunity such as conversation practice, roleplaying...etc., seemed to be very good. She added that typical expressions or more notetaking might be introduced in class, also mentioned self-repetitions are necessary to be included. She seemed to have no stress to work with other classmates who had higher levels of Spanish as well as knowledge about Japanese culture.

Regarding the case of S9, his mood slightly becomes better for each category after the class, except AT in June 2018 and no change of GB and AT in June 2019. Due to some missing data, May 2018 was not included in Figure 4.
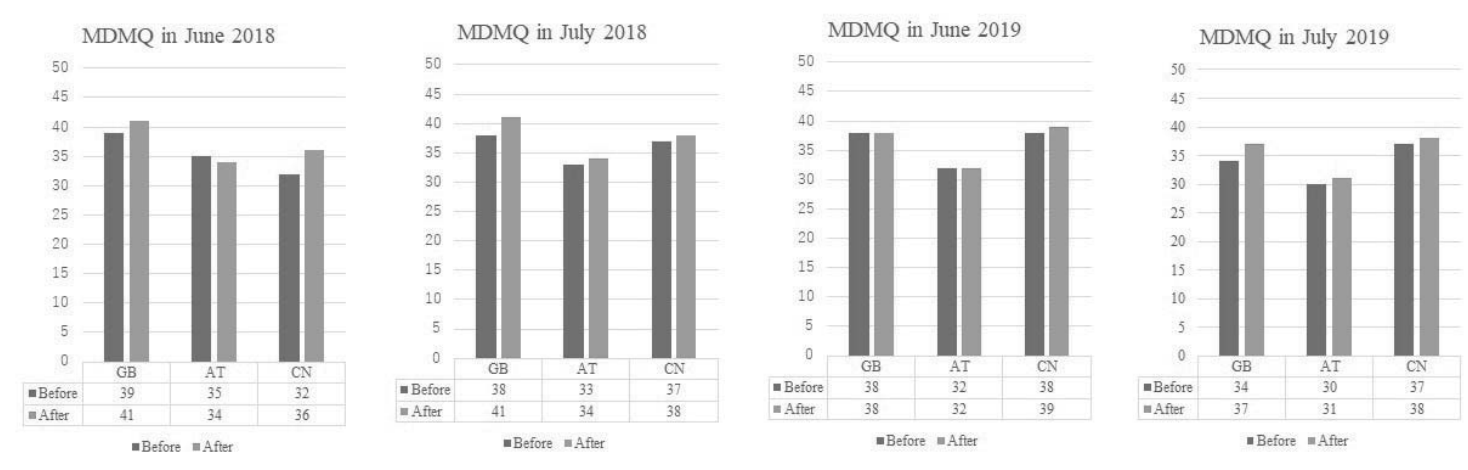

Figure 4.

Results of the Multidimensional Mood State Questionnaire (MDMQ) of S9

Source: Author's research upon questionnaire

He followed the volunteer tour guide course from the spring of 2018 and continued in the spring of 2019. His Spanish level was considered B2 both in 2018 and 2019. He studied Spanish for nine years previously and had travelled once to Spain. He explained that the motivation for studying this language was that he had been impressed by his colleagues' level of Spanish. His motivation to follow this volunteer tour guide course was to improve his conversation skills. Table 5 demonstrates some highlights from his diary. 
Table 5.

Highlights of the diary from S9.

\begin{tabular}{|c|c|}
\hline Spring, 2018 & pring, 2019 \\
\hline $\begin{array}{l}\text { "I enjoyed thinking and explaining a topic about } \\
\text { Japan in Spanish by group. The usual things for } \\
\text { us are actually very special to foreign people } \\
\text { and it was a special experience to be asked the } \\
\text { questions on that" (April 18, 2018). }\end{array}$ & \multirow{2}{*}{$\begin{array}{l}\text { "Similar exercises from previous } \\
\text { year on Jizo were repeated. Without } \\
\text { talking too deeply, we tried to explain } \\
\text { in an easy and clear manner by using } \\
\text { question and answer dialogues, and } \\
\text { the texts were checked by our teachers } \\
\text { in advance" (May 29, 2019). }\end{array}$} \\
\hline $\begin{array}{l}\text { "The teacher explains and immediately wrote on } \\
\text { the board with corrections. It was very useful for } \\
\text { learning" (April 18, 2018). }\end{array}$ & \\
\hline $\begin{array}{l}\text { "The teachers are more familiar with some } \\
\text { topics than us. As wrap-up and some exercise, } \\
\text { that learners from each group tried to respond } \\
\text { to the questions by the teacher who played the } \\
\text { role of a guest was very good. I appreciate it that } \\
\text { we have four [native] teachers leading this class" } \\
\text { (April } 25,2018) \text {. }\end{array}$ & $\begin{array}{l}\text { "Presentation on Jizo was demonstrated } \\
\text { in pairs. It was a similar activity to the one } \\
\text { last year, we concentrated on explaining } \\
\text { in simple terms and in an easy way to } \\
\text { understand. I noticed that we minded less } \\
\text { about making grammatical mistakes and } \\
\text { focused on what we wanted to transfer to } \\
\text { the guests" (June } 5,2019 \text { ). }\end{array}$ \\
\hline $\begin{array}{l}\text { "I made a pre } \\
\text { While prepari } \\
\text { think a lot of s } \\
\text { relationships } \\
\text { Buddhism" (M }\end{array}$ & \multirow{2}{*}{$\begin{array}{l}\text { "Today's class was self-study format } \\
\text { and we researched and worked with } \\
\text { the group. Teachers gave advice by } \\
\text { walking around the class. This style of } \\
\text { class activity seems to give chances or } \\
\text { to encourage Japanese learners who } \\
\text { are not used to speaking in front of } \\
\text { the class" (June 26, 2019). }\end{array}$} \\
\hline $\begin{array}{l}\text { "We } \\
\text { using } \\
\text { it wa } \\
\text { to ad } \\
\text { prese }\end{array}$ & \\
\hline $\begin{array}{l}\text { "Role practice with teac } \\
\text { of guests and learners } \mathrm{n} \\
\text { enjoyable as teachers pr } \\
\text { including unexpected o }\end{array}$ & \multirow{2}{*}{$\begin{array}{l}\text { „We first made presentations } \\
\text { individually using Question \& Answer } \\
\text { about New Year's Day in Japan and } \\
\text { the teacher added some corrections } \\
\text { on Spanish texts. Then, we practiced } \\
\text { explaining Japanese annual events, } \\
\text { such as, Obon, 7-5-3 (Shichi Go San). } \\
\text { Once we started to explain the Japanese } \\
\text { events, we had too much information. } \\
\text { We were reminded to think of using } \\
\text { What, When, Where, How, and For } \\
\text { what to explain in detail” (July 3, 2019). }\end{array}$} \\
\hline $\begin{array}{l}\text { nonstrated pair work in front of } \\
\text { by video taking. Different from the } \\
\text { class, everyone started to demonstrate } \\
\text { sentations without checking the texts, it } \\
\text { that difficult words were avoided and } \\
\text { it seemed easy to understand" (July 4, }\end{array}$ & \\
\hline $\begin{array}{l}\text { "Later, we changed partners and practiced the } \\
\text { role-playing. It was a fresh experience. This } \\
\text { seems to be an interesting opportunity to practice } \\
\text { with all the class members" (July 4, 2018). }\end{array}$ & \multirow{2}{*}{$\begin{array}{l}\text { "In class, I made a presentation in the } \\
\text { pair on Hakata Gion Yamakasa. I spent } \\
\text { lots of time for researching. Since our } \\
\text { prepared texts had a lot of corrections, it } \\
\text { was difficult to organise the information } \\
\text { before my presentation. However, } \\
\text { thanks to the number of teachers in } \\
\text { class, we have proper correction of texts } \\
\text { and I appreciate it" (July 10, 2019). }\end{array}$} \\
\hline $\begin{array}{l}\text { "We made a plan for a day trip to Kyoto by the } \\
\text { group. It was difficult to agree on the contents } \\
\text { within my group for presentations" (July 18, } \\
\text { 2018). }\end{array}$ & \\
\hline
\end{tabular}

Note: translation by authors

Source: author's research 
This learner is clearly aware that this type of learning leads to a lesser focus on grammatical mistakes and a larger focus on conveying contents to the visitors. According to the interview, role-playing, making conversations, discussion practices had not been much practiced in his studying experience in language learning before, but he mentioned that he had no stress at all in the class, especially in this tour guide course. He does not mind even if he cannot learn fast or not. Experiencing another role to behave like a guest is also interesting. It seems that his good fundamental level of Spanish gave him the enjoyment to be able to express himself better in a foreign language than feeling some psychological burden to perform in a foreign language.

\section{DISCUSSION}

At the start of the tour guide course in 2018, as a leaner mentioned, some learners had higher levels of Spanish such as having experience using Spanish for business or having deeper knowledge about Japanese culture. Their group work activities revealed the difficulty of having consensus among different proficiency levels of learners in a foreign language. They needed to learn different techniques or ways of communication with the group; as another learner indicated such communicative or discussion-oriented approach in their language learning experience had been missing. As we experienced in class, some learners felt ambiguous in course content in class and their frustrations without knowing how to proceed and deal with the work with other group members with different levels or experience lead younger teachers to change the class organisation. If it does not happen as they believe it should, some do not continue the course the following semester and others, as the cases demonstrated here, try to rethink or create better ideas and strategies to tackle the ambiguous situation while learning.

We actually observed few masculinity reactions during group work or in their diaries or interviews of the language learning classroom. Most of them have some international experience and additional language learning experience apart from their school learning with different cultures and people and it seems that they are well aware of such typical gaps in the classroom between females and males in Japan. They are careful enough to pay attention to this point. According to the results of mood questionnaire, as S13's case showed, her mood improved a lot almost all the time after the class. It means that when they are not confident with their Spanish level, women might show their anxiety more than men before the class. On the other hand, some women are often willing to challenge new things and continue or restart the course. This might indicate that tolerance of ambiguity in women is not always simply affected by the proficiency level of languages; as long as they feel a sense of achievement, they seem to be satisfied. In contrast, men generally seem to prefer undertaking difficult tasks that they have sufficient levels or concrete objectives following the distribution of the group level (the majority of male 
participants in this course are B2 level and no participant is lower than B1 level both in 2018 and 2019).

Concerning their life experience and motivation, the diaries and the interviews show that learners focus less and less on their mistakes and more and more on being useful to the visitors through sharing their knowledge of Japan with them in an efficient and useful way.

\section{CONCLUSION}

A content-based course linked to practical occasions to be a volunteer tour guide seems not simple to carry out. On the other hand, most of the learners' mood in terms of actual state of wellbeing, being awake and alert, and calmness seemed better after the class most of the periods according to the result of their mood questionnaires (MDMQ questionnaire). Some learners felt ambiguous about the content and the course was challenging as we discovered from their introspective materials, however, independently of their Spanish level, they tried to find simple and alternative ways/solutions to manage the conversations or explanations. The communication style class using group works or role-plays with classmates of the same generation and younger teachers had enjoyable aspects that were reflected in the improvement visible in the mood questionnaires (MDMQ questionnaire) after the class. This type of activity in which the tour guides support guests from foreign countries with welcoming spirit (Omotenashi) requires that they apply their life long language learning experience and is the source of motivation to keep learning.

Practicing listening to others' comments and preparing texts for writing or speaking, they seemed to be able to output with their words not only by translating from Japanese. It must be stated, however, that a considerable amount of work was necessary to achieve these results. The course is taught by four native teachers, all of whom are present in the classroom. They had to work hard to take learners out of their fixed ways of explaining Japanese history in detail, or of seeking a correct answer for any query that a visitor may have (for instance, about the meaning of religious symbols, etc., many explanations are available, and learners felt uncomfortable with this at the beginning, but with time, and as it becomes clear from the interviews and diaries, they understand that they need to simplify and focus on explaining things clearly and on accepting ambiguity).

This course was slightly different from typical cases in Japan, though, because their language level and experience/knowledge seem more important for the class atmosphere in this content-based L2 learning. Some objectives or projects such as a speech contest, travelling abroad, volunteer guiding, or even practicing in class, are crucial for their motivation to keep learning L2. Role-playing, discussion and other communicative practices could be effective ways for this type of L2 learning even though it is challenging for them, according to their diaries and interviews. 
Future work will focus on analysing every one of the participants qualitatively, and will also include interviews with the teachers of the course. Whereas it seems as though this type of volunteer tour guide course is an appropriate way to get older adults to learn language better (recall that most of the learners analysed in this paper had raised their level of Spanish from the first course to the second), there are many aspects that need to be refined: for instance, how to convince them earlier about the need to adjust their explanations about Japanese culture in a realistic way to their language level without having this constitute a source of frustration for the low ambiguity-tolerant generation.

\section{REFERENCES}

[1] Amano, M. (2009). II Gakkou kuukan - Byoudou to sexism no koubou [School space Offense and defense in equality and sexism] (p. 60). [In:] M. Amano, K. Ito, R. Ito, T. Inoue, C. Ueno, Y. Ehara, M. Osawa, M. Kanou, \& M. Saito. (Eds.), Shinpen Nihon no feminism 8 Gender to kyouiku [New version Feminism in Japan 8 Gender and education]. Tokyo, Japan: Iwanami Shoten, Publishers.

[2] Bin Ya Shak, M. S. (2015). Tolerance of ambiguity and the use of language learning strategies among ESL learners at the tertiary level. Retrieved from https://pdfs.semanticscholar.org/ad59/ e792dffa964f3c7611b413b62d36e496f7c8.pdf

[3] Budner, S. (1962). Intolerance of ambiguity as a personality variable. Journal of Personality, 30(1), 29-50. https://doi.org/10.1111/j.1467-6494.1962.tb02303.x

[4] Cabinet office, Government of Japan. (2018). Chapter 2 Situation Regarding Implementation of Measures for the Ageing Society. Annual Report on the Aging Society. Retrieved from: https:// www8.cao.go.jp/kourei/english/annualreport/2018/pdf/c2.pdf

[5] Council of Europe. (2001). Common European Framework of Reference for Languages: Learning, teaching, assessment. Cambridge: Cambridge University Press.

[6] Department of Methodology and Evaluation Research, University of Jena. (n.d.). $M D M Q$ questionnaire (English version of MDBF). Retrieved from: https:/ / www.metheval.uni-jena.de/ mdbf.php

[7] Hofstede, G., Hofstede, G. J., \& Minkov, M. (2010). Cultures and organizations: Software of the mind, Third edition. New York: NY: McGraw-Hill.

[8] Inoue, H. (1989). Maekoujou [Introduction]. Juippiki no neko [Eleven cats], Komatsuza the 座 [The $z a], 14,16-17$.

[9] Kachmaryk, K., Grabovska, S., Ostrovska, K., \& Syniev, V. (2014). Tolerance for uncertainty in elderly people. Journal of Education Culture and Society, 5(1), 20-27. doi:10.15503/ jecs20141-20-27.

[10] Kawaguchi, A. (2013). Nihon no gender wo kangaeru [Discussing gender roles in Japan]. Tokyo, Japan: Yuhikaku publishing.

[11] Marzban, A., Barati, H., \& Moinzadeh, A. (2012). An investigation into ambiguity tolerance in Iranian senior EFL undergraduates. English Language Teaching, 5(1), 76-85.

[12] Mori, S. (2009). Seiyakuwari no gakushuu to shitsukekoui [Gender role learning and discipline] (pp. 61-70). [In:] M. Amano, K. Ito, R. Ito, T. Inoue, C. Ueno, Y. Ehara, M. Osawa, M. Kanou, \& M. Saito. (Eds.), Shinpen Nihon no feminism 8 Gender to kyouiku [New version Feminism in Japan 8 Gender and education]. Tokyo, Japan: Iwanami Shoten, Publishers.

[13] Muramatsu, Y. (2003). Gakkoukyouiku to gender: Kenkyuu to jissen no doukou [School education and gender: Research trends and practical questions]. 学術の動向 [TRENDS IN THE SCIENCES], 8(4), 36-40.

[14] Muramatsu, Y. (2009). Kagakugijutsu to gender [Science technology and gender] (pp. 261272). [In:] M. Amano, K. Ito, R. Ito, T. Inoue, C. Ueno, Y. Ehara, M. Osawa, M. Kanou, \& M. Saito. (Eds.), Shinpen Nihon no feminism 8 Gender to kyouiku [New version Feminism in Japan 8 Gender and education]. Tokyo, Japan: Iwanami Shoten, Publishers. (In Japanese) 
[15] Naiman, N., Fröhlich, M., Stern, H. H., \& Todesco, A. (1996). The Good Language Learner. Clevedon: Multilingual Matters.

[16] Norton, R., W. (1975). Measurement of Ambiguity Tolerance. Journal of Personality Assessment, 39(6), 607-619.

[17] Ramírez Gómez, D. (2016). Language teaching and the older adult: The Significance of experience. Bristol: Multilingual Matters.

[18] Shibuya, E. (2018). L2 learning for seniors: Lessons from an exchange between Japanese learners of Spanish and a senior volunteer guide group from Spain. Journal of Linguistic and Cultural Studies, (50), 3-11.

[19] Shibuya, E. (2019). MEXT policies and learning experience: Lifelong learners of languages other than English. Language Policy, Innovations and Practices: A Tale of Two Countries. Kobe City University of Foreign Studies Journal of Research Institute, 59, 39-53.

[20] Steyer, R., Schwenkmezger, P., Notz, P., \& Eid, M. (1997). Der Mehrdimensionale Befindlichkeitsfragebogen (MDBF). Göttingen, Germany: Hogrefe.

[21] Yoshihara, K. (1995). Joshidaigakusei niokeru shokugyousentaku no mechanism Joseinaibunka no youin toshiteno joseisei [Job Selection of Women University Students: Femininity as a Factor of Intra-Gender (Women) Differentiation]. 教育社会学研究 [The Journal of Educational Sociology], 57, 107-124. 